Summer 2007

\title{
Civil Society Constitutionalism: the Power of Contract Law
}

\author{
Marc Amstutz \\ University Freiburg/Switzerland \\ Adreas Abegg \\ University Freiburg/Switzerland \\ Vaios Karavas \\ University Freiburg/Switzerland
}

Follow this and additional works at: https://www.repository.law.indiana.edu/ijgls

Part of the Contracts Commons, Government Contracts Commons, and the International Law

\section{Commons}

\section{Recommended Citation}

Amstutz, Marc; Abegg, Adreas; and Karavas, Vaios (2007) "Civil Society Constitutionalism: the Power of Contract Law," Indiana Journal of Global Legal Studies: Vol. 14 : Iss. 2 , Article 3.

Available at: https://www.repository.law.indiana.edu/ijgls/vol14/iss2/3

This Symposium is brought to you for free and open access by the Law School Journals at Digital Repository @ Maurer Law. It has been accepted for inclusion in Indiana Journal of Global Legal Studies by an authorized editor of Digital Repository @ Maurer Law. For more information, please contact rvaughan@indiana.edu.

\section{$\Psi$}

JEROME HALL LAW LIBRARY

INDIANA UNIVERSITY

Maurer School of Law
Blooming ton 


\title{
Civil Society Constitutionalism: The Power of Contract Law
}

\author{
Marc Amstutz,"Andreas AbegG,"“ \& Vaios Karavas"**
}

\begin{abstract}
This article argues that the vision of a social law of contract is exhibited in the judgment of the Swiss Federal Court in Post v. Verein gegen Tierfabriken ("VgT"). The judgment is one of a law of contract that interacts with a community of the subjects instead of the individual subjects of a community. This paper contends that law today has the task of providing for the areas of social autonomy from which "civil society" is built up and in which, at the same time, the increasing social fragmentation can be overcome piecemeal. The article argues that conceiving contract law as civil society constitutionalism, as the constitution not of the state but of society, is the jurisprudential task for our time.
\end{abstract}

\section{From Subject to Society}

The starting point of our considerations is the judgment of the Swiss Federal Court in Post v. Verein gegen Tierfabriken ("VgT").' For behind this judgment, a powerful vision shines through: the vision of a social law of contract. This vision does not conform with Gierke's sense of a private law lubricated with "socialist oil,"2

- Marc Amstutz, Prof. Dr., LL.M., University Freiburg/Switzerland.

• Andreas Abegg, Dr. iur., LL.M., Lecturer, University of Freiburg/Switzerland.

-.. Vaios Karavas, Dr. iur., LL.M., Lecturer, University of Freiburg/Switzerland.

1. Post v. Verein gegen Tierfabriken, Bundesgericht [BGer] [Federal Court] May 7, 2002, 129 Entscheidungen des Schweizerishchen Bundesgerichts [BGE] III 35 (Switz.).

2. Otto von Gierke, Die soziale Aufgabe des Privatrechts 10 (2d ed. 1948). The oft-cited, but false, reference to "social oil" first appears, as far as we know, in Franz Wieacker, PrivatRECHTSGESCHICHTE DER NEUZEIT: UNTER BESONDERER BERÜCKSICHTIGUNG DER DEUTSCHEN ENTWICKLUNG 470 ( $2 \mathrm{~d}$ ed. 1967).

Indiana Journal of Global Legal Studies Vol. 14 \#2 (Summer 2007)

OIndiana University School of Law 
the communitarian sense of Macneil, ${ }^{3}$ or the post-class struggle sense of the Study Group on Social Justice in European Private Law. The picture appearing behind the judgment is instead one of a law of contract that interacts with society as such and not just with individuals (for example, the rich versus the poor, the strong versus the weak, or the independent versus the dependent), who always embody only a part of society. This law is social in the original meaning of the word: it abandons its bias in favor of the subjects of a community and takes sides with a community of the subjects.

This proposition is not to be seen as a mere play on words. It points out that today's law of contract can no longer, in liberal fashion, content itself with enabling and facilitating legal transactions. Contract law today has the further task of providing for the areas of social autonomy from which "civil society" is built up and in which, at the same time, the increasing social fragmentation can be overcome piecemeal. Conceiving contract law as civil society constitutionalism, as the constitution not of the state but of society, is the jurisprudential task for our time. In Post v. VgT, the Federal Court has, in the outcome at any rate, begun to do this job. It has sought to develop first elements for this sort of understanding of contract law, something that has so far-wrongly, we feel—brought it almost exclusively censure and criticism. ${ }^{5}$

\section{A. Individual Dispute Versus Conflict of Discourses}

What was it about? The story is simple on the surface: in late 1999 the VgT ("Association against Animal Factories") gave the Post two of its quarterly publica-

3. Ian R. Macneil, The New Social Contract: An Inquiry into Modern Contractual Relations (1980).

4. Study Group on Social Justice in European Private Law, Social Justice in European Contract Law: A Manifesto, 10 Eur. L.J. 653 (2004).

5. Legal scholars rejected Post v. VGT almost unanimously, except for 1 Peter Gauch, Walter R. Schluep \& Jörg Schmid, Schweizerisches Obligationenrecht: Allgemeiner Teil note $1115 \mathrm{a}$ (8th ed. 2003) and Tarkan Göksu, Gedanken zur Kontrahierungspflicht anlässlich von BGE 129 III 35, 140 ZBJV 35 (2004). It is noteworthy that this attitude was adopted by almost all the authors, i.e. not just private lawyers but also constitutionalists and administrative lawyers, who commented on the judgment. See, e.g., Ruth Arnet, Bemerkungen zu BGE 129 III 35, AJP 593 (2003); Eugen Bucher, Nicht «Kontrahierungspflicht - Schon eher Schutz vor Boykott, 83 RECH 101 (2003); Yvo Hangartner, Art. 35 BV. Frage der Bindung eines öffentlichen Unternehmens (Post) an die Grundrechte bei privatrechtlicher Tätigkeit im Wettbewerb mit Privaten, 6 AкtuelLe JuRistische Praxis [AJP] 690 (2003); Madeleine Camprubi, Kontrahierungszwang gemäss BGE 129 III 35: ein Verstoss gegen die Wirtschaftsfreiheit: zugleich ein Beitrag zur Diskussion über die Grundrechtsbindung von öffentlichen Unternehmen, 4 AJP 384 (2004). 
tions, printed in a total of 700,000 copies, unaddressed for mass mailing to Germanand French-speaking Swiss households. The Post refused the mailing. It explained its refusal on the ground that the publications would damage its reputation and hamper its business, since they criticized various farmers, who might feel compelled because of the mailing to question their business relations with the Post. According to the facts of the case taken by the court as the basis for its judgment, there were no alternatives open to $\mathrm{VgT}^{6}$ That is, other firms that could have distributed the magazines as efficiently as the Post were not (yet) available in 1999.

The nature of the conflict reflected in these facts is the really interesting (and difficult) thing about the case because this conflict takes place between parties that do not move in the same societal sphere. The Post primarily operates in the economy, whereas the VgT is active in media and politics. Camprubi identifies this difference as a "dilemma underlying the decision" and states that "[t]he Post, undoubtedly to be termed - as the Federal Court does in the present case-an enterprise with a strong [economic] power position, turned down a potential customer $[\mathrm{VgT}]$, with the effect that the latter was de facto restricted in the propagation of its political opinions." "What does not emerge from these certainly accurate observations is the fact that, over and above the subjective dispute, a conflict of discourses, as described by Lyotard, is present, i.e., a clash of different social rationalities, namely one between economic and political discourse. ${ }^{8}$ This is the key to understanding Post v. VgT. For the discursive dimension of this clash, going beyond the mere subjective dispute between Post and VgT, shows that the issues that the judgment seeks to tackle lie in the choice of criteria for settling a dispute between two realms of society that cannot be reduced to a common denominator (for example, money, political power, or protection of animal life). If, however, neither economic, political, nor ecological criteria can do justice to this clash, can there be some other reference (of a new type), which in casu may reconcile the conflict in a socially acceptable manner? What might this third perspective actually be?

\section{B. The New Private-law Society}

The Federal Court's considerations in the Post $v$. VgT judgment are built on a plan that seems to stick to the traditional hierarchy of the legal system. Thus, the court first verified whether postal legislation provides in casu for a duty to deliver.

\footnotetext{
6. Post, 129 BGE III at 46.

7. Camprubi, supra note 5 , at 396 (translated by author).

8. Jean-François Lyotard, Discours, ficure (1971).
} 
It first recalls that, since the postal legislation reform of January $1,1998,{ }^{9}$ the Post has been organizationally independent of the federal administration and is a public-law entity with its own legal personality. Subsequently, the Federal Court asks whether the Post, as a legal person operating under private law in a context of competitive services, infringed, by its refusal to distribute the $\operatorname{Vg} T$ publications, on "media freedom, specifically freedom of the press." 10 The lower court had answered in the affirmative on the ground that the Post, as a public-law entity, was bound to preserve the constitutional rights, irrespective of the legal form under which it was operating. The Federal Court decided otherwise, reasoning that since the Post was not acting as a "state actor" in the area of competitive services, the constitutional rights on the basis of the Swiss Federal Constitution (Cst.) art. 35(2) did not come into consideration. " Nor could any such requirement follow from Cst. art. 35(1), since the legislator had clearly wanted the Post to be on the same footing in the area of competitive services as its private competitors. ${ }^{12}$

An interim observation on this point: the Federal Court's considerations on "state action" referred to above, like the exposition of administrative law in Post $v$. $V g T$, ought not to be read from the view point of the traditional dichotomy between state and society. This has been implicitly denied by Hangartner. In a critical assessment of the judgment, he notes that "state action" within the meaning of Cst. art. 35(2) refers to "any State activity or [any activity] attributable to the State."13 Correspondingly, the Post in casu — contrary to the Federal Court's view - was bound by the constitutional provisions, and the refusal to distribute the VgT publications did infringe media freedom. This position may be defensible according to classical constitutional rights doctrine, but fails to see that the constitutional rights question discussed in Post $v . V g T$ arises in a context of privatization. Ultimately, privatization means a fundamental reorganization of various social functions. Such context radically changes the premises of traditional constitutional rights theory.

\section{A Question of Perspective}

After declining to consider the Post a state actor, the Federal Court deliberates about the possibility of the horizontal effect of constitutional rights (Drittwirkung)

9. Postgesetz [PG] [Swiss Post Act] Apr. 30, 1997, SR 783.0 (Switz.).

10. Post, 129 BGE III at 40.

11. Id., ground 5.2 .

12. Id. at 41 , ground 5.3 .

13. Hangartner, supra note 5, at 692 (emphasis added). 
under Cst. art. 35(3). This is, however, set aside uninvestigated, "because it ... will follow from purely private-law considerations that the Post was not entitled ... to refuse the distribution of [the VgT publications]."14 This sentence has to be seen as the pivot of the judgment: what is ultimately being announced here is nothing less than an attempt at structural adaptation of the legal system-in particular the threadbare private-public law dichotomy - to the reorganization of societal functions brought by the privatization wave in the 1990s. This endeavor amounts to a program of Herculean dimensions. That such a program cannot be set on foot through a single supreme court decision is manifest. Accordingly, Post v. $V g T$ remains an outline for the moment, and while it does point in a certain direction, its reasoning still needs to be further thought through in many respects. However, we shall go into that later. First, we must look at the Federal Court's private-law solution to the case.

The first sentence in ground six makes clear what the point is: "A distribution obligation on the Post, which in the area of competitive services-like its private competitors - acts within the forms of private law, exists where an obligation to contract is to be presumed."15 Since in the case at hand no precontractual or framework obligation to perform exists, the Federal Court looks for a statutory basis, but finds no provision explicitly calling for an obligation to contract, and accordingly asks "whether such [an obligation] ... may also follow from ... general principles of private law." ${ }^{16}$ After considering the seminal Seelig decision ${ }^{17}$ and taking an excursus through the scholarship, the Federal Court answers in the affirmative. It stresses that contractual freedom "has, as an element of private autonomy, an extremely high place in the private-law system." ${ }^{18}$ Accordingly, restrictions on the freedom to conclude contracts have a "markedly exceptional character." The prohibition of immoral conduct can be used to derive an obligation to contract only under the following cumulative conditions:

An obligation to contract on this basis presupposes, first, that an undertaking offer its goods or services generally and publicly.... Second, the obligation to contract can relate only to goods and services satisfying ordinary needs.... Third, an obligation to contract

14. Post, 129 BGE III at 42.

15. Id.

16. Id.

17. Bundesgericht [BGer] [Federal Court] Feb.2, 1954, 80 Entscheidungen des Schweizerischen Bundesgerichts [BGE] II 26 (Switz.).

18. Post, 129 BGE III at 45. 
can be assumed only where the interested party lacks, because of the supplier's strong power position, acceptable alternatives for meeting his ordinary need.... Fourth, an obligation to contract can be assumed only where the undertaking can give no objectively justified reasons for refusing to conclude the contract. ${ }^{19}$

In the case in point, the Federal Court finds these requirements to be met, and concludes, as a judicial determination, from this finding that " $[u]$ nder these circumstances the Post's refusal to carry the plaintiff's [VgT's] publications is contra bonos mores. The Post would accordingly have been under obligation to carry the plaintiff's consignments on the terms it had... publicly and generally announced." 20

Legal scholars raised a storm against this part of the judgment, claiming, for example, that the judgment overshot the target, ${ }^{21}$ contradicted elementary logic, ${ }^{22}$ departed from the history of civil law, ${ }^{23}$ constituted normative exaggeration of mere mores, ${ }^{24}$ and raised methodical objections. ${ }^{25}$ These harsh words indicate that the discussion around Post v. $V g T$ was no longer just about mere differences of legal scholarship. If, however, legal scholarship no longer helps, how can the judgment's meaning be further unpacked?

\section{Polycontexturalization of the Law of Contract}

To elucidate the significance of Post $v . V g T$, and especially the emergent structures of a law of contract to be understood, in the sense described, as "social," we wish to use the tools of Law \& Society scholarship. ${ }^{26}$ By contrast with legal doctrine, which concentrates on the constructability of a solution within the set of legal rules in force, Law \& Society scholars consider the legal system from the

19. Id. at $45-46$, ground 6.3 .

20. Id. at 47 , ground 6.4 .

21. Camprubi, supra note 5, at 403.

22. Bucher, supra note 5 , at 106.

23. Id.

24. Id. at 108 .

25. Arnet, supra note 5, at 596.

26. For a discussion on the sociological observation of private and economic law, see Marc Amstutz, Historizismus im Wirtschaftsrecht, in Festschrift für Jean Nicolas Druey (Rainer J. Schweizer, Herbert Burkert \& Urs Gasser eds., 2002). 
outside. ${ }^{27}$ The gain this offers is a description of the means whereby the law interacts with society at large. This, however, first calls for a look at the particularities of today's society.

\section{A. Günther's “Mehrwertige Logik”}

It is possible to see the Federal Court's search for new forms of social reciprocity through the law of contract as a reaction to privatization. ${ }^{28}$ It remains undisputed that the phenomenon of privatization brings with it a creeping de-solidarization of society. This calls for a functional equivalent to public law, the grip of which disappears in the privatized sector and which can now hardly, if at all, guarantee social peace. Were we to stop at this stage of the analysis, we would be overlooking the fact that a more fundamental problem lies behind Post v. VgT-the problem of the polycontexturalization of society. For the phenomenon of privatization is ultimately-with all the reservations that such a statement requires - a response to the fragmentation of society into increasingly numerous autonomous sectors, of which the coordination and administration by a central body, namely the state, is gradually becoming implausible. Against this background we must consider what is the specific feature of the polycontextural society to which Post $v$. $T g V$ seems to be trying to adapt the law of contract.

A description of the polycontextural society should start from the "mehrwertige Logik" developed by Günther, which notably continues and expands on the findings of Hegel. ${ }^{29}$ Günther is chiefly concerned with replacing the current monocontextuality with a new logic that fits in with so-called transmodern science. In contrast with a classical binary logic (e.g., subject/object or paradise/hell), held together-in monocontextual fashion-by something all-embracing, that is, an Absolute such as the world-spirit or an all-powerful god, Günther's logic takes on a multiplicity of values. These values in turn set up new binary logics or contextures, making the universe appear to be polycontextural..$^{30}$ In social contexts,

27. See, e.g., Niklas Luhmann, Law as a Social System 257-62 (Fatima Kastner, Richard Nobles, David Schiff \& Rosamund Ziegert eds., Klaus A. Ziegert, trans., 2004); DAN WIELsch, FreIheit und Funktion: Zur Struktur- und Theoriegeschichte des Rechts der WIRTSCHAFTSGESELLSCHAFT 23 (2001).

28. See, e.g., Bucher, supra note 5, at 102.

29. See 3 Gotthard Günther, Beiträge zur Grundlegung einer operationsfähigen DiaLEKTIK 183-210 (1980).

30. Id. at 196-97; see also 2 Gotthard Günther, Beiträge zur Grundlegung einer operationsfähigen Dialektik 191-92, 297 (1979); $c f$. Niklas Luhmann, Einführung in die System- 
these binary contextures combine to create interlinked contextures displaying far higher complexity. ${ }^{31}$

The structure of today's society can be described from Günther's viewpoint as a differentiated one insofar as variously specialized areas of action have developed out of combinations of individual contextures that follow a common "context-rationality." This sort of simultaneous coexistence of various operationally autonomous logics of action, which, however, relate to and interact with each other, gives rise to a society of great structural complexity; from Günther's viewpoint, it should be stressed that society, understood as interlinked contextures, differs decisively from its individual parts. Very roughly, economic rationality follows profit as the leading difference (valuable / worthless), politics relates to the rationality of power (powerful / powerless), while science is interested primarily in the search for truth (true / false) and art in the search for beauty (aesthetic/ unaesthetic). ${ }^{32}$ Every communication happens simultaneously in various contexts. Any communication, say about new unemployment figures, is thus simultaneously specifically economic, legal, and political communication.

\section{B. The Conceptual Readiness of the Law of Contract}

What does all this have to do with the law of contract? The foregoing statements suggest that in Post $v$. VgT the court attempted to orient the law of contract to the polycontexturality of society in the sense of securing the wealth of contexts against tendencies of whatever kind to overwhelm them. ${ }^{33}$ Put more concretely, the judgment seems to have employed the figure of an obligation to contract as a tool to prevent the economy from blocking political discourse. This raises the question of whether the law of contract really has the capacity to perform such a function. Or does it at first sight lack the conceptual readiness to serve this type of polycontextural constitutionalization function?

THEORIE 67 (2002) (referring to Ferdinand de Saussure).

31. 2 GünTHER, supra note 30, at 191-92.

32. Marc Amstutz, Vertragskollisionen: Fragmente für eine Lehre von der Vertragsverbindung, in Aktuelle Aspekte des Schuld- und Sachenrechts: Festschrift für Heinz Rey zum 60. Geburtstac 161, 165 (Heinrich Honsell, Wolfgang Portmann, Roger Zäch \& Dieter Zobl eds., 2003). For a more general discussion of relational contracting, see Gunther Teubner, Contracting Worlds: The Many Autonomies of Private Law, 9 Soc. \& Legal Stud. 399, 405, 407-10 (2000).

33. See Dieter Hart, Zur konzeptionellen Entwicklung des Vertragsrechts, 29 AG 66, 72 (1984); Teubner, supra note 32, at 412-14; Rudolf Wiethölter, Sozialwissenschaftliche Modelle im Wirtschaftstecht, 18 KRITIsche Justiz [KJ] 126, 130-31 (1985). 
From a historical perspective, nothing argues essentially against this conceptual readiness of the law of contract; right from the beginnings of market society, contract law has played a key role in constituting economic autonomies and making them compatible with other social contexts. In nineteenth century society, the need was to ensure the necessary basis of trust in contractual relations between individuals and to protect the individual from being deprived of contractual freedom, thereby legally enabling and pushing forward the differentiation of the economic system. In the twentieth century, the de facto freedom of action of broad strata of the population was achieved, thereby making the differentiated economy compatible with other social areas through political concepts. ${ }^{34}$ After Post $v . V g T$, it is now more strongly the constitution of the intrinsic rationality of the various areas of social autonomy that are central to the task of the law of contract, not least as a response to the policy of privatization.

\section{Civil Constitution I: Integration of the Polycontextural Society}

If, against the background of the foregoing explanations, the thesis that the law of contract ought to be considered further as a civil constitution has gained a certain plausibility, then the point now is how this new task is to be fleshed out in detail. What has Post v. VgT to teach us in this respect? Can this fleshing-out in case law act as a basis for constitutionalizing the multiple, continually self-renewing contexts of society?

Before addressing these questions, we should clarify what is meant by the term "civil constitution." Why do we speak here of "constitution," when what is at issue in Post v. $\mathrm{VgT}$ is, in substantive law terms, classical (bipolar) contract law? In other words, for what reason is a civil constitution, in addition to the traditional state constitution, required in the polycontextural society? Once this preliminary question is answered, we will discuss the question of what social forces are used in Post v. VgT in order to integrate society through the use of private law.

34. See, e.g., Eugen Ehrlich, Das zwingende und nichtzwingende Recht im Bürgerlichen Gesetzbuch für das Deutsche Reich 65 (1899); von Gierke, supra note 2, at 12-16; Anton Menger, Das Bürgerliche Recht und die besitzlosen Volksklassen 153-54 (5th ed. 1997); Philipp Lotmar, Der Dienstvertrag des zweiten Entwurfes eines bürgerlichen Gesetzbuches für das Deutsche Reich, in Philipp Lotmar: Schriften zu Arbeitsrecht, Zivilrecht und Rechtsphilosophie 97, 169 (Joachim Rückert ed., 1992). 


\section{A. Constitution "From Below"}

The most advanced ideas about the concept of a civil constitution today come from those scholars who deal with the globalization of law. Their thoughts focus on the idea of a societal constitutionalism, ${ }^{35}$ or of a "constitutionalisation without the state. ${ }^{36}$ At the center of this idea is the notion that the constitution of transnational communities (for instance, the transnational economy, international sport, and the Internet) comes not from above but from below.

Grotius' famous proposition ubi societas ibi ius has to be reformulated in the conditions of the functional differentiation of the planet in such a way that, wherever autonomous social sectors develop, autonomous law is simultaneously produced, at a relative distance from politics. Law-making also takes place outside the classical sources of international law, in agreements between global players, in private market regulation by multi-national concerns, internal regulations of international organisations, inter-organisational negotiating systems, world-wide standardisation processes that come about partly in markets, and partly in processes of negotiation among organisations.... If it is true that the dominant sources of global law are now to be found at the peripheries of law, at the boundaries with other sectors of world society, and no longer in the existing centres of law-making - national parliaments, global legislative institutions and inter-governmental agreements - then, this simultaneously also means that norms of constitutional quality are always being produced there. ${ }^{37}$

Plainly, everything then depends on the possibility of defining criteria that identify the "norms of constitutional quality." The discussion now gets caught in the maelstrom of innumerable concepts of constitution offered in the literature. ${ }^{38}$

35. Cf. David Sciulli, Theory of Societal Constitutionalism: Foundations of a Non-Marxist Critical Theory (1992) (providing an alternative understanding of this term).

36. Gunther Teubner, Societal Constitutionalism: Alternatives to State-Centred Constitutional Theory?, in Transnational Governance and Constitutionalism 3, 8 (Christian Joerges, IngerJohanne Sand \& Gunther Teubner eds., 2004).

37. Id. at 16-17.

38. See, e.g., Bardo Fassbender, The United Nations Charter as Constitution of the International Community, 36 Colum. J. Transnat'L L. 529, 538-51 (1998) (surveying three different schools of 
Today, there seems to be some consensus that, conceptually, one should talk about a constitution only if norms have emerged that (1) limit and guide into ordered pathways the capacity of the legal system and society to influence each other (criterion of Rechtsstaatlichkeit), (2) define the ways of producing law in H.L.A. Hart's sense of setting up secondary norms and stopping "arbitrary" normativity (criterion of positivization of law), ${ }^{39}$ and (3) lay down the constitutional rights standards that every legal communication must meet (criterion of self-regulation of law).$^{40}$ This self-regulation is not confined to formal laws, but also extends to general terms of trade, private standards, and the like; the aim is the legal liberation, but, at the same time, the curbing, of system-specific rationality vis-à-vis internal spontaneous order and other sectors of society. ${ }^{41}$

\section{B. Constitution as "Integrative Reality"}

Post v. $\operatorname{VgT}$ is concerned not with the civil constitution of sectors of world society that have differentiated in the wake of globalization, but with something else: the consequences that the polycontexturalization of society has for existing law-that is, the question of how the legal system must, in consequence of the many shifts due to society's polycontexturalization, be internally reorganized. ${ }^{42} \mathrm{~A}$ polycontextural society, as we describe it above, is, inter alia, distinguished by the absence of any body able to take on responsibility for the whole.

There is [for instance] no subsystem for the ecology, and even were such a subsystem to form, it would be in competition with other subsystems and would first have to assert its claim to recognition. This problem might be termed the "Tower-of-Babel syndrome"...

thought on the adoption of constitutional arguments).

39. See H.L.A. Hart, The Concept of Law 185-212 (2d ed. 1997).

40. See, e.g., Gunnar Folke Schuppert \& Christian Bumke, Die Konstitutionalisierung der Rechtsordnung: Überlegungen zum Verhältnis von verfassungsrechtlicher AusstrahLUNGSWIRKUNG UND EigenstüNDIGK EIT DES «EINFACHEN》 RECHTS 29-35 (2000) (containing one of many relevant surveys).

41. Teubner, supra note 36 , at $24-27$.

42. For some decades now this discussion has been about whether the public law / private law distinction still makes sense, or ought to be replaced by some other systematization. E.g., MARTIN Bullinger, Öffentliches Recht und Privatrecht (1968). The formula "internal reorganization of the legal system" used in the text is an attempt to reorient this discussion, ultimately unsatisfactory in outcome, in sociological terms. Id. 
[Social integration]... might fail because of the multiplicity of codes and the poor communication between subsystems. ${ }^{43}$

The question then is what can still hold a polycontextural society together. If this type of society is distinguished by the fact that its subsystems each have their own rationalities, making mutual understanding difficult, or even impossible, while at the same time coordination "from above," by some central body such as the parliament or government, appears unrealistic, then one thing should be clear: the hierarchical concept of constitution suited to the nation state, which is supposed to constitutionalize not just the state but the whole society, can no longer stand up. What ways out are there, then, in this situation?

It is here that we should draw inspiration from the discussion on "constitutionalisation without the state," even though, in relation to the issues we are dealing with, it cannot be adopted as-is. It is not confined to outlining the concept of constitution, but also raises the question of what the constitution of a fragmented society actually ought to achieve. Yet, of some importance is Teubner's statement that the "constitution of world society ... [cannot] take place in a unitary global constitution which overlies all areas of society, but, instead, emerges incrementally in the constitutionalisation of a multiplicity of autonomous sub-systems of world society." ${ }^{\text {"44 }}$ It is just this notion of incremental constitutionalization of autonomous social discourses that we need to use to illuminate and extend the project embarked on in Post $v$. VgT.

In this connection we would recall that in polycontextural society the civil society "zones" are not directly visible to politics and still less deliberately influenceable by it. Politics, the traditional constitutional lawmaker, lacks the knowledge and the means to grasp and guide the evolutionary processes of civil society, which are increasingly radicalized in their dynamics. Accordingly, civil society is struggling today, more than ever-as it were for structural reasons-against being constitutionalized on the pattern of the state constitution. This pattern is of course still open in content, but nonetheless sets goals and, to that extent, starts from a teleological picture of the social order. ${ }^{45}$ It thus prescribes an order that moves within a clear range of variation laid down by politics. In the evolutionary

43. Manfred Aschke, Die Verfassung des Experiments Moderne, 6 Rechtsgeschichte 101, 108 (2005).

44. Teubner, supra note 36 , at 8 .

45. For further discussion on the image of the "teleological social system," see KarL-Heinz Ladeur, Negative Freiheitsrechte und cesellschaftliche Selbstorganisation: Die ErzeuGUng von Sozialkapital dURCh Institutionen (2000). 
process of civil society, by contrast, there is hardly ever an even halfway stable boundary drawn between social sectors, nor are their respective functions ever durably fixed. The range of variation is unlimited from the viewpoint of politics. Thus, prescribed goals based on a teleological social model inevitably miss the intended effect. Polycontextural society continually reconfigures itself, living from discourses that emerge and disappear again, replace each other, and during their existence continually change their concrete form. ${ }^{46}$

That is precisely why, in its non-political areas, civil society needs a constitution that follows a different logic from that of classical state constitutionalism, which, while institutionally confined to the political processes, has the ambition to constitutionalize the whole of society in this way. ${ }^{47}$ This logic is different because it is to be conceived incrementally, i.e., it functions dynamically, organically, and in contextrelated fashion. Essentially, this means the need is not to lay down some preset order planned on fixed parameters, but to find an "external constitution, ${ }^{48}$ or a "géométrie variable. ${ }^{, 49}$ Synchronization between social discourses cannot come about through rational calculation but only in pragmatic fashion. Due to ever changing circumstances such a synchronization is only ever valid in relation to a particular point in time. It cannot therefore be durable and must continually be redone. The principle of an incremental constitution of autonomous social systems lies from this viewpoint not in creating an order fleshed out in substantive law, but in making available supporting instruments enabling these systems to create from their own resources their (respective) order, that is, their civil constitution. Correspondingly, the function of this sort of civil constitution can be described entirely in the categories of Smend's integrationist concept of constitution, which describes an integration process that, while definitely not aiming at "continually recreating the living totality of

46. To that extent, this form of society is the essence of our "reflexive modernity." See Scott Lash, Reflexivität und ihre Doppelungen: Struktur, Asthetik und Gemeinschaft, in RefLexive ModernisierUnG: Eine Kontroverse 195 (Ulrich Beck, Anthony Giddens \& Scott Lash eds., 1996).

47. For a discussion on this remarkable oscillation of the State-centred concept of constitution between restriction to politics and overall social order, see Niklas Luhmann, Die Politik der Gesellschaft 201, 207-08, 217 (André Kieserling ed., 2002) and Teubner, supra note, 36 at 7-8. Post v. VGT in particular is an outstanding example for bringing out how classical constitutionalism with its dual claim simultaneously to constitute politics and society is de facto no longer able to operate in the "private" spheres, at least not always. And simply leaving these areas to themselves seems - as the factual situation underlying this judgment clearly shows - hardly defensible.

48. 2 Jürgen Habermas, The Theory of Communicative Action: Lifeworld and System: A Critique of Functionalist Reason 371 (Thomas McCarthy trans., Beacon Press 1987) (1981).

49. Marc Amstutz, Evolutorisches Wirtschaftsrecht: Vorstudien zum Recht und seiner Methode in den Diskurskollisionen der Marktgesellschaft 84 (2001). 
the State,"50 nevertheless integrates-in parallel with the state constitution-anew the various social discourses. In short, Smend suggests that civil constitution is "integrative reality"s1_-a description that is appropriate particularly because the term "reality" brings with it a connotation of fluctuation, as reality never stands still.

\section{Extension of the Area of Dispute in Contract Law}

One might also delineate the problem from the viewpoint of the debate on privatization (always bearing in mind that privatization stands, under certain circumstances, in direct connection with social polycontexturalization). ${ }^{52}$ It would then be seen that those social areas dismissed into the private sphere have by no means thereby lost their need for constitutionalization. They continue to need integration into the social whole, i.e., the definition of their relations with each other and with the whole of society.

Public law will, for the reasons just mentioned above, be able to offer little support for this integration. ${ }^{53}$ It relates its concerns solely to the state, and has lost its relevance for the formerly public, now private, functions of these sectors. One might consider filling this gap by expanding public law and its principles so that this complex of norms would also cover the privatized areas. This is the key idea of the theory that postulates that private actors are always bound by constitutional rights whenever their action still contain remnants of a former public task (state action doctrine). ${ }^{54}$ Post $v . V g T$ is in contradiction with this doctrine, as the message of the judgment is that the integration of the non-state sectors of society cannot possibly be secured through a closed system on the pattern of traditional public law, but only "by liberating evolutionary processes of self-regulation and systembuilding." 55 The judgment recognized that there was no prospect of stopping the game of permanent differentiation of society, as the traditional constitutional legislator once sought to do. On our reading, the message to be decoded from Post $v$. $V g T$ is that there is only one way forward: to seek means to enable the conflicting

50. Rudolf Smend, Verfassung und Verfassungsrecht 78 (1928).

51. Id. at 80 .

52. See supra Part III.B.

53. Savigny's view that only public law was able to integrate law of property into society is, of course, today and for the future no longer defensible. See 1 Friedrich Carl von Savigny, System of the Modern Roman Law, at 299-308 (William Holloway trans., Hyperion Press 1979) (1867).

54. See supra Part I.B.

55. Aschke, supra note 43, at 117 (translated by authors). 
social autonomies lastingly to restore "practical concordance" themselves whenever necessary. ${ }^{56}$

This is perhaps the most far-sighted aspect of Post $v$. $\operatorname{VgT}$. Instead of somehow applying public law to privatized sectors where it does not fit, this judgment mobilizes the historically developed constitutionalization function of the law of contract. To be sure, this function has hitherto been confined to a very specific, purely economic constitutionalization objective, which we may sum up in the key phrase "market constitutionalization." 57 The job to be done in Post v. VgT was, accordingly, to make these civil-constitution elements, embodied in the general contract law of obligations, fruitful for the polycontextural society as a whole. But can these elements be detached from their economic reference and be extended to other social systems?

This question raises the problem of how the civil constiturional function of the law of contract can be reflected in terms of legal technique. Basically, in legal scholarship and legal theory, two approaches have been developed that might aid this discussion: (1) the theory of the horizontal effect of constitutional rights, and (2) the concept of discursive rights proposed by Teubner and Graber.

\section{Civil Constitution II: Fleshing Out the Integrative Function of Contract Law}

\section{A. Horizontal Effect of Constitutional Rights}

In Post v. VgT, the Federal Court, as we have described, ${ }^{58}$ felt it "needless" to employ the doctrine of the horizontal effect of constitutional rights. What lies behind this choice? Is its application determined solely by the circumstances of the individual case or should more be seen in it? It would be quite conceivable that the highest court wanted, for purely practical reasons, to avoid the dangerous reefs of a scarcely controllable conflict of constitutional rights. For in Post $v . \mathrm{VgT}$, economic freedom and media freedom clashed "frontally," both mutually incompatible, and, therefore, each struggling for exclusive application. ${ }^{59}$ To seek to me-

56. See also id.

57. Marc Amstutz, Andreas A begg \& Vaios Karavas, Soziales Vertragsrecht 27 (2006).

58. See supra Part I.C.

59. Without here pre-empting the subsequent analysis (see infra Part V), let us note that for third-party effect, basic rights suffer from a sort of "structural inadequacy": it is only in asymmetry that they can function at all; where basic rights are "symmetrized," i.e., distributed evenly on both sides of a conflict relation. It is no longer clear whether the one right or the counter-right takes 
diate in this situation between two constitutional rights would have triggered the limits of what could still be justified. The Federal Court would thereby have ended up striking a "trade off" that is as common as it is vacuous. ${ }^{60}$ "Trade off," as a legal method, seeks to determine the circumstances of the individual case precisely, so as to justify priority in concreto for the one or the orher constitutional rights position. But that is illusory. A conflict of two incompatible constitutional rights cannot be solved by calculating, from a juridical evaluation of the legal facts, the "right" solution. ${ }^{61}$ Even if the solution then presented bears the appearance of argumentative rationality, it is, and remains, the outcome of a vague "gut feeling" and amounts to either politics disguised in legal form or methodological arbitrariness.

Besides this fairly practical explanation, there are probably also deeper reasons for the Federal Court's reluctance in the case at hand to opt for a solution based on the horizontal effect of constitutional rights. The problematic aspect of the theory of horizontal effect of constitutional rights is more the transfer of the political constitution to civil society. Liberal constitutional rights theory is correct in this point-the constitutional rights, as institutionalized in the political constitution, are in fact to be seen as political rights, won by citizens in long struggles against the state. ${ }^{62}$ This speaks against applying them directly to private persons, as the theory of the horizontal effect of constitutional rights postulates. Relations between private persons obey a different logic from that governing relations between citizens and the state. A direct transfer of the political values inherent in the constitutional rights to non-state areas would not only contribute to a colonization of these areas by politics, but would scarcely be capable of opposing the dangers to autonomy arising from the intrinsic dynamics of the respective nonstate area.

To summarize, in the polycontextural society, the theories of the horizontal effect of constitutional rights cannot provide any real help because they remain stuck with the notion that either the judge (theory of direct horizontal effect) or the legislature (theory of the constitutional duty of the state to protect the private

primacy. For an early study that demonstrates this point, see H.C. NIPPERDEY, GRUNDRECHTE UND Privatrecht 18-19 (1961).

60. See, e.g., Claus-Wilhelm Canaris, Grundrechte und Privatrecht: eine Zwischen bilanz 73 (1999).

61. Cf. Gunther Teubner, Ein Fall von struktureller Korruption? Die Familienbürgschaft in der Kollision unverträglicher Handlungslogiken (BVerfGE 89, 214 ff.), 83 K RITV 388 (2000).

62. For an example from Germany, see 1 Gert Brügcemeier, Entwicklung des Rechts im organisifrten Kapitalismus 44 (1977). 
sphere) can determine the correct outcome in applying constitutional rights to private-law relations through recourse to a sovereign-planned order built into these institutions. The private actors are by contrast reduced to objects of state or of judicial protective policy. The constitutionalization of private-law relations is, however, brought about by a corresponding instrumentalization of law from above and with no reference to the knowledge accumulated through the self-organization processes in non-state areas, or to the expectations developed in these knowledge-building processes. ${ }^{63}$ In the conditions of an innovation-oriented, knowledge-based society, the existence of which depends primarily on the achievements of the private sector, as well as on radical shifts in the performance of social functions (especially in the privatization debate), even these newer approaches to an indirect effect of constitutional rights prove to be inadequate attempts at creating a normative structure for guaranteeing areas of social autonomy.

\section{B. Theory of Discursive Rights}

What, finally, are the chances for Teubner's and Graber's theory of discursive rights to grasp the basic idea of Post $v . V g T$ and, thus, put the integrative function of private law into words? Generally speaking, these authors seek to extend Luhmann's system-theory treatment of constitutional rights into a generalized approach addressing intersystem conflicts. They aim at developing impersonal discursive rights that protect one social discourse (e.g., art) in danger of being overwhelmed, i.e., having its rationality affected, by another (e.g., the economy). ${ }^{64}$ Such an effect on one social system's rationality occurs, in the example of art versus economy, if, for instance, broadcasters interrupt transmissions of films with commercial advertising breaks, thus hampering the arousal of artistically appropriate impressions in the viewer. In this specific case, discursive rights would work as follows: "The moral right of the author [is] re-interpreted as a constitutional right which protects the integrity of artistic communication against infringements not by the State, but by an economic enterprise."65

63. See, e.g., Karl-Heinz Ladeur, Kritik der Abwägung in der Grundrechts-dogmatik 60 (2004).

64. Teubner defines "discursive rights" as "impersonal rights of certain spheres of communication, founded in constitutional law and directed in a horizontal direction against the intrusions of any social system with hegemonic tendencies." Gunther Teubner, After Privatisation? The Many Autonomies of Private Law, in 51 Current Legal Problems 1998: Legal Theory at the End of the Millennium 393, 421 (M.D.A. Freeman ed., 1998).

65. Christoph Beat Graber \& Gunther Teubner, Art and Money: Constitutional Rights in the Private Sphere?, 18 Oxford J. Legal Stud. 61, 72 (1998). 
This approach does not aim at the replacement of constitutional rights as guarantees of individual autonomy. Instead, this system is to be supplementedthat is, it must be recognized that the sphere of the self-realizing individual is only one of the many areas of freedom that are secured by constitutional rights. ${ }^{66} \mathrm{To}$ that extent, it is only consistent for the theory of discursive rights to take off from private law as the main arsenal of legal institutions serving individual possibilities of development in our society.

[C]onstitutional rights understood as discourse rights can be seen as cornerstones for a reconstruction of private law. Contemporary private law must see one of its main tasks in the protection of the many private autonomies, not only against the repressive state but also against the expansionist tendencies of technology, science and the market. ${ }^{67}$

Thus, Teubner's strategy is focused primarily on doing away with the colonization of one rationality by another by means of law, so as to uphold society's differentiation, in the existing form. However, the question of how the conflicting systems and other systems indirectly involved in the dispure (notably law, but also politics and science) perceive each other and, in a process of co-evolution, reorient their operations and structures to the changed environmental demands (or else reject reorientation) is barely addressed. The same applies to the question of the role the law is to play in this process of co-evolution. In short, the concept so sensitively developed by Teubner, concentrated on maintaining the differentiated systems in polycontextural society, needs to be supplemented by a concept of co-evolution specific to the law.

Turning now to the irritations proceeding from Post $v . V g T$, we may see in them possibilities of softer ways for the law to deal with social norms. A reading of the judges' considerations arouses the impression that the Federal Court was concerned with updating the civil constitutional function of contract law more through selective protection of certain systemic mechanisms than by allowing across-the-board system protection. Bearing in mind the insights the analysis of the theories of horizontal effect, negative freedoms, and discursive rights has brought us, the question that next arises is whether the Federal Court's procedure

66. See Teubner, supra note 32, at 412-13; see also Graber \& Teubner, supra note 65, at 66 (stating that constitutional rights can simultaneously protect multiple spheres of action).

67. Teubner, supra note 32, at 413. 
can be explained on a basis of evolutionary jurisprudence and rendered into the form of a technical legal concept.

\section{Civil Constitution III: Structural Coupling and the Evolution of Legal Discourses}

\section{A. Evolutionary Jurisprudence and the Reflexivity of Civil Constitutionalism}

Evolutionary Jurisprudence is a recent research approach in legal scholarship, starting from the point that the law cannot be the creation of one human mind, however brilliant. ${ }^{68}$ It sees denial of this fact as the most fatal error of contemporary legal scholarship. Its concern is to show that one can do without a deliberately planned design of law and, nevertheless, explain how nothing in the world of law happens arbitrarily. This non-arbitrariness does not-as in classical legal approaches-come about because law rests on eternal values (such as God, justice, or efficiency). Instead, it is guaranteed by the fact that law stands in a conditional equilibrium with society, so that there is a sort of homeostasis between them. In other words, this fragile and demanding relationship between law and society depends on society's capacity to evolve. Accordingly, the law's rules must be designed to fit this principle of laisser-faire for evolution.

This proposition is of course paradoxical. Certainly, law is the design of society; to that extent, it might very well be seen as the counterpart to evolution. However, and this is the source of the paradox, this counterpart is itself also evolution. For evolution is omnipresent and ubiquitous! The attempt to resolve the paradox should thus be made by seeking to illuminate the basic rules of evolutionary jurisprudence mentioned through a comparison with the procedure of animal breeders. Just as they play with evolutionary mechanisms while in no way obstructing, but rather exploiting, them on the basis of relevant accumulated experience- "selecting selection," one might say-so too does evolutionary jurisprudence play with the mechanisms of societal evolution with the aim, as we said, of replacing

68. For a discussion on the evolutionary theory of law, see, for example, Amstutz, supra note 49; Marie Theres Fögen, Römische Rechtsgeschichten: Über Ursprung und Evolution eines sozinlen Systems (2002); Andreas Abegg, Evolutorische Rechtstheorie, in Neue Theorien des Rechts 371 (Sonja Buckel, Ralph Christensen \& Andreas Fischer-Lecano eds., 2006); Okko Behrends, Rudolf von Jhering und die Evolutionstheorie des Rechts, in Privatrecht heute und Jherings evolutionäres Rechtsdenken 7 (Okko Behrends ed., 1993); and Okko Behrends, Jherings Evolutionstheorie des Rechts zwischen Historischer Rechtsschule und Moderne, in RUdOLF vON JHERING: IsT die Jurisprudenz eine Wissenscha ft? 94 (Okko Behrends ed., 1998). 
the undiscoverable, yet in the praxis of law taken for granted, "supreme canon" of law ("God," etc.) by the mechanism of "social homeostasis."

An evolutionary interpretation of Post $v$. $V g T$ has to start by asking what social task the constitutionalization of the law of contract is seeking to accomplish. We showed earlier that this task is the integration of polycontextural society. ${ }^{69}$ The divergent social discourses of civil society, continually evolving, always changing, emerging again in new forms, and gradually disappearing or being replaced by new sorts of discourses, are to be given an order able to ensure practical concordance between them. This sort of order must inevitably be autological, i.e., set up self-referentially, since no legislator can foresee the development of an evolving polycontextural society and correspondingly lay down an appropriate order. It follows that civil constitutionalism is to be understood as a corpus of rules that do not authoritatively lay down a particular order, but utilize the reflexive potential of the social areas concerned so as to achieve the goal pursued, namely social integration through self-created order. ${ }^{70}$

\section{B. Structural Coupling as Evolutionary Mechanism}

Against the background of these connections, it must be asked: how is it conceivable that individual social areas (e.g., the economy or art) can adjust to each other, that is, integrate socially, and thus mitigate or avoid potential or actual conflicts? If these social areas are understood in a communicative sense, and thus grasped as systems in the sense of modern systems theory, then one possible answer is that social integration comes about through the mechanism of structural coupling. This answer in turn poses a number of hard questions. They are hard particularly because the concept of structural coupling holds a central place in systems theory. It is the only way for the "environment to influence a system," so behind it lies the riddle of how social systems develop mutually suited structures and ensure the cohesion of society. But what exactly is to be understood by the term structural coupling?

Ultimately, it denotes a system's adaptation to its environment; for instance, with living creatures, the fact that their muscles are coordinated with the force of gravity on Earth to enable their movements on land, in water, or in the air, which are requirements for their survival, or that creatures with eyes and ears can, to-

69. See supra Part II.

70. See supra Part III.B.

71. 1 Niklas Luhmann, Die Gesellschaft der Gesellschaft 101 (1997). 
gether with their brains, grasp some narrow physical bandwidth of their environment so as to orient their operations to it. ${ }^{2}$ These examples show that restrictions on structural coupling have drastic consequences for a system. Such restrictions may affect the conditions for it to be able to adapt its specific way of operating, that is, its autonomy (or in systems-theory jargon, its autopoiesis) in its environment. ${ }^{73}$ For the system itself, accordingly, structural coupling means an "area" in which "opportunities [are] stored, which the system can use, can convert into information." ${ }^{\text {"T }}$ The term structural coupling first of all denotes "a system's relation to the environmental requirements that ... have to be met, have to be given, to be able to continue its autopoiesis." 75 By contrast, operative couplings-as a counterconcept-merely synchronize operations with each other, i.e., are not lastingly oriented to the existence of particular structures in the environment, but merely link up momentarily to other operations for one event only. ${ }^{76}$

But this is only one side of the coin. The description of structural coupling as a system's existential relation to its environment also suggests that this relation contains the conditions for the system to act environmentally compatibly, i.e., to integrate socially. For if Luhmann uses the term structural coupling to denote the fact that a system continually presumes particular features of its environment and structurally relies on them, ${ }^{77}$ he simultaneously implies that the system reflects the consequences of its behavior for the environment and is, to that extent, aware of the importance of the environment's integrity for its own autopoiesis. By linking its operations to the structural coupling, the system limits its internal excesses of capacity and thus tolerates restriction of its freedom. ${ }^{78}$ Since structural coupling means both the system's capacity to deal with its environment and its dependency on that environment, we can see that this mechanism is the relay station for the integration of the system (for example, law, politics, the economy, art, or religion) into the overall system (society).

Therefore, it is essential for sociology to understand this mechanism betterspecifically, to decipher its existential and functional conditions. However, on this very point there are not inconsiderable differences of opinion among scholars. Ac-

72. See Lummann, supra note 27 , at 382-83.

73. LuHMANN, supra note 71 , at 107.

74. LuHManN, supra note 47 , at 121.

75. Claudio Baraldi, Giancarlo Corsi \& Elena Esposito, Glossar zu Niklas luhmanns Theorie sozialer Systeme 186 (2d ed. 1998) (translated by authors).

76. Lummann, supra note 27 , at 381.

77. See, e.g., Luhmann, supra note 71, at 106.

78. Id. at 101 . 
cording to a basic rule of systems theory, it is the social system's structures (not environmental influences) that determine its evolution. Luhmann, therefore, rejects "any notion of explaining the evolution of social systems that contains any tendency, of whatever nature, for social systems to adapt to their environment."79 Accordingly, structural coupling could not be explained as a consequence of evolution. Luhmann states in this regard:

for it [the theory of autopoietic systems], adaptedness is a precondition, not an outcome, of evolution; and an outcome, if at all, only in the sense that evolution destroys its material if it can no longer guarantee adaptedness. The burden of explanation is now borne by the concept of "structural coupling." For structural coupling has always guaranteed adaptation adequate for the continuation of autopoiesis. $^{80}$

Aschke has raised significant objections to this view. Essentially, he sees it as rooted in theory-structure constraints on systems theory. He argues that Luhmann, with his thesis that structural coupling is not a consequence but a precondition of evolution, is concerned only with harmonizing evolutionary theory with his theory of autopoietic systems. The price for this harmonization is the exclusion of all external value parameters, which are dependent on the environment and which are needed for the differential reproduction of the social system. This in turn has the consequence that structural couplings cannot convincingly be explained as an outcome of evolution. ${ }^{81}$ That Luhmann dismisses the whole issue with the remark, "The determination of a beginning, an origin, a 'source' and a 'before' (or none) ... is a myth generated in the system itself - or a tale by another observer," ${ }^{82}$ is regarded by Aschke as a pis aller. ${ }^{83}$

Perhaps Aschke's dismissive attitude, though correctly putting a finger on a vulnerable point in Luhmann's theory, is, after all, too hasty. We believe that Luhmann's thesis of structural coupling as a precondition for evolution does point in the right direction, as long as one is prepared to reassess the thesis in light of

79. Manfred Aschke, Kommunikation, Koordination und soziales System: Theoretische Grundlagen für die Erklärung der Evolution von Kultur und Gesellschaft 98 (2002) (translated by authors).

80. LuhmanN, supra note 71 , at 446 (translated by authors).

81. AschKe, supra note 79, at 121.

82. LuHMANN, supra note 71 , at 441 (translated by authors).

83. AschKE, supra note 79 , at 113-14. 
more recent findings of evolutionary theory. What we have in mind is the work of Kauffman, who, in years of experimentation with complex gene systems, developed a theory to which we can make recourse here. ${ }^{84}$ Very briefly, the theory consists of the following three propositions: (1) by contrast with the hitherto dominant Darwinian version, evolution does not have a single central agency, but rather two, namely selection and spontaneous organization; (2) selection presupposes spontaneous organization, or, in other words, the selection mechanism works only as long as the evolving system possesses the capacity to organize itself spontaneously; and (3) this capacity for spontaneous organization depends on a particular internal set of relations of the system's elements, which enables it to absorb perturbations from its environment in such a way as not to endanger its operational capacity (that is, its autopoiesis). ${ }^{85}$

This theory has many implications for evolutionary theory, which cannot all be explored here. The most important thing is simply that it suggests revising our understanding of the selection function-its role is not to structure the evolving system in such a way that it adapts to its environment, but rather, like a sort of search engine, to guide the (already adapted) system to where its evolutionary prospects can be improved. Even if at first sight the difference may seem slight, it has one significant consequence: the process of evolution does not constitute an environmentally steered unfolding of the properties of the evolving system. Instead, evolution is only possible because, from the outset, a logic is present in the system that ensures its capacity for evolution. The conclusion to be drawn is that structural coupling comes about in the evolutionary factor of spontaneous formation of order. That is, it is directly associated with the system's capacity for spontaneous (self-) organization shown by Kauffman.

\section{Conclusion}

This reconstruction of the concept of structural coupling enables an interpretation of the civil constitutionalism by way of the law of contract envisaged by the Federal Court in Post v. VgT in terms of legal evolution. The Federal Court has intervened in the system of socicty as a whole at the very place where the subareas of society supplement and mutually support each other: the locus of their structural couplings. More specifically, in the Post $v . \operatorname{Vg} T$ judgment, the Federal

84. Stuart Kauffman, At Home in the Universe (1995).

85. For a more detailed discussion of Kauffman's theory, see Amstutz, supra note 49, at 278-88. 
Court did not set the political discourse entirely above the economy, but confined itself to upholding, through the means of the obligation to contract, the link between the societal sectors on which politics structurally relies and is dependent for its autopoiesis.

The resemblance to the concept of discursive rights cannot be overlooked. However, while the theory of discursive rights starts from the endangerment of one discourse by another (as in the example of family surety described) and works across the board in systems-theory terms (through nullity of the surety), ${ }^{86}$ it is enough, following the evolutionary-theory concept favored here, for the law to concentrate on the strategic points in the network of societal communication, that is, on the structural couplings. A systems-theory reading of Post v. $V g T$ points in this direction. The Federal Court went step by step in this judgment and-one might say in wise judicial self-restraint-confined itself to a soberly realistic protection of the evolutionary capacity of the politics discourse. This procedure is wise especially because it does justice to the nature of a polycontextural society. If it is true that this type of society is typified by permanence-oriented change of its components, the social discourses, then it would be contradictory to impose on the discourse of law the task of integrating diverging discourses, which have become just as foreign to each other as to the law, in authoritative fashion.

Behind the civil constitutionalism of the Federal Court's judgment lies yet more, namely a subtlety that becomes properly visible only through the lens of evolutionary jurisprudence. It does not try to restore structural coupling between the economy and politics-as the relation between social systems upon which social cohesion rests - through the obligation to contract. Instead, it only (but importantly) gives judicial support to an already existing structural coupling between the economic and politics discourses. It thereby upholds the possibility of social integration and does so only to the extent that the politics system relies structurally on the economy.

86. See Teubner, supra note 32 , at $412-13$. 